\title{
Kronika Katedry Nauk Historycznoprawnych Wydziału Prawa Uniwersytetu w Białymstoku (2011 rok)
}

Najważniejszym wydarzeniem w życiu Katedry był wybór Piotra Fiedorczyka jako jedynego reprezentanta Polski na członka Rady Wykonawczej Międzynarodowego Stowarzyszenia Prawa Rodzinnego (International Society of Family Law). Wyboru dokonano podczas Światowego Kongresu Międzynarodowego Stowarzyszenia Prawa Rodzinnego Generation Solidarities. The Ties that Bind. Obligations Between Generations, który odbył się w lipcu 2011 r. w Lyonie. Z kolei w listopadzie 2011 r. Krzysztof Szczygielski uczestniczył w Międzynarodowej Konferencji Naukowej Pace e fondamentalismo religioso, zorganizowanej w Bari (Włochy). Wygłosił tam referat: Leeducazione alla pace nella famiglia: aspetti etico-giuridici. Podczas VIII międzynarodowej konferencji naukowej Prawo a prywatność, która odbyła się w Białymstoku w kwietniu 2011 r., Karol Kuźmicz wygłosił referat zatytułowany Zagadnienie prywatności w utopiach $i$ antyutopiach.

Krzysztof Szczygielski uczestniczył w Ogólnopolskiej Interdyscyplinarnej Konferencji Naukowej Instytucja rodziny wczoraj i dziś (Warszawa, grudzień 2011 r.), gdzie wygłosił referat Rodzina w świetle uchwał synodów diecezjalnych w Polsce po ogłoszeniu Kodeksu Prawa Kanonicznego z 1983 r. Karol Kuźmicz podczas XI konferencji Katedry Filozofii Prawa Wyższej Szkoły Menadżerskiej w Warszawie oraz Pacyfistycznego Stowarzyszenia i Polskiego Stowarzyszenia Kultury Europejskiej (SEC) Wielopoziomowy i wielopłaszczyznowy rozwój człowieka jako warunek rzeczywistej demokracji (Kuźnica na Helu, październik 2011 r.) wystąpił z referatem Człowieczeństwo w obliczu rozwoju technologicznego.

Spośród publikacji autorstwa pracowników Katedry w języku angielskim ukazały się artykuły:

Piotra Fiedorczyka The Catholic Church and the Reform of Family Law in the 20th Century Poland, [w:] Essays in Honour of Penelope Agallopoulou, Athens 2011, t. I;

Krzysztofa Szczygielskiego Roman Law in Education of the New Generations of Lawyers - the Polish Experience, [w:] Historical Legal Systems and European Integration, Collection of Papers from the International Scholastic Conference Law as a Unifying Factor of Europe - Jurisprudence and Practice organised by the Comenius University in Bratislava, Faculty of Law on $21^{\text {st }}-23^{\text {rd }}$ of October 2010, Bratislava 2011;

Piotra Kołodko, Lex poetelia de ambitu of 358 b.c. as an example of legislation against corruption in elections, "Studies in Logic, Grammar and Rhetoric" 2011, 24 (37); 
Karola Kuźmicza Liberalism and Utopia, „Studies in Logic, Grammar and Rhetoric" 2011, Vol. 24 (37),

Piotra Niczyporuka, Mensarii, bankers acting for public and private benefis, „Studies in Logic, Grammar and Rhetoric” 2011, 24 (37).

Ponadto Piotr Fiedorczyk był autorem podrozdziału History of Polish Law podręcznika Legal English, który został wydany w Białymstoku w $2011 \mathrm{r}$.

Na łamach „Czasopisma Prawno-Historycznego" ukazał się artykuł Diany Maksymiuk $W$ sprawie demokratyzacji wymiaru sprawiedliwości” - „Prawo i $\dot{Z} y$ cie” i inne czasopisma prawnicze w roku 1956 w Polsce („CPH” 2011, Tom LXIII, Zeszyt 1). Marcin Łysko zamieścił artykuł Orzecznictwo karno-administracyj$n e w$ walce $z$ alkoholizmem $w$ okresie gomulkowskim w katowickim periodyku „Z Dziejów Prawa”, t. 4 (12). W ramach materiałów pokonferencyjnych w „Zeszytach Prawniczych" Uniwersytetu Kardynała Stefana Wyszyńskiego ukazały się drukiem referaty:

- Piotra Fiedorczyka, Polski kodeks rodzinny z 1950 r. Czy przełom?, „Zeszyty Prawnicze" 2011, nr 11.2;

- Piotra Kołodko, Lex Calpurnia de pecunis repetundis" i jej znaczenie dla ewolucji rzymskiego prawa karnego, „Zeszyty Prawnicze” 2011, nr 11.1;

- Karola Kuźmicza, Prawo w utopii komunistycznej. Zarys problematyki, „Zeszyty Prawnicze” 2011, nr 11.4;

- Marcina Łysko, Przełom roku 1956 w Polsce a orzecznictwo karno-administracyjne, „Zeszyty Prawnicze” 2011, nr 11.3;

- Diany Maksymiuk, Rok 1956 w Polsce - dyskusje prawników o sądach, prokuraturach i prawie karnym, „Zeszyty Prawnicze” 2011, nr 11.4;

- Krzysztofa Szczygielskiego, Romanistyka polska w latach 1918-1945 (Przegląd bibliografii), „Zeszyty Prawnicze” 2010, nr 10.2.

W styczniu 2011 r. Marcin Łysko uzyskał grant badawczy pt. „Prawo karno-administracyjne Polski Ludowej (1951-1971)”, natomiast w ramach grantu „Urzędy w starożytnym Rzymie okresu republiki i pryncypatu” Piotr Niczyporuk i Piotr Kołodko prowadzili kwerendę naukową na rzymskim Universitá degli studi di Roma, LA SAPIENZA (październik - listopad 2011). W listopadzie 2011 r. Krzysztof Szczygielski przebywał na Wydziale Prawa Università di Bari (Włochy), gdzie wygłosił wykład Legal effects of concubinage in Polish law. 